\title{
ANALISIS PENAMPANG FONDASI TIANG PANCANG PADA TEPI TANAH REKLAMASI
}

\author{
Rendy $^{1}$ dan Aniek Prihatiningsih ${ }^{2}$ \\ ${ }^{1}$ Program Studi Sarjana Teknik Sipil, Universitas Tarumanagara, Jl. Letjen S. Parman No.1 Jakarta \\ rendy.325170048@stu.untar.ac.id \\ ${ }^{2}$ Program Studi Sarjana Teknik Sipil, Universitas Tarumanagara, Jl. Letjen S. Parman No.1 Jakarta \\ aniekp@ft.untar.ac.id
}

\begin{abstract}
Indonesia is a country with $4^{\text {th }}$ largest population in the world. With that huge amount of population, the land capacity on the mainland is becoming more limited day by day, on the other hand, the unused land on the coast is still not utilized properly. The solution of that problem is by doing reclamation on the coast. Reclamation is an activity to increase the usability of land resources in the eye of the environmental side, social and economy by doing dropping, land drying, or drainage. Usually, the material for dropping reclamation is using cohesive soil. In this research, we will talk about driven pile foundation on reclamation land. Bearing capacity and concrete volume that would be used from every driven pile shape would be compared by paying attention from scouring effect that can decrease the bearing capacity of the pile. In this study, we will show the best driven pile shape that can be used on reclamation land.
\end{abstract}

Key Word: reclamation, foundation, driven pile, bearing capacity, scouring.

\begin{abstract}
ABSTRAK
Indonesia merupakan negara dengan jumlah penduduk terbanyak ke empat di dunia. Dengan banyaknya penduduk di Indonesia mengakibatkan lahan di daratan semakin terbatas, sedangkan lahan di sekitar pinggir pantai masih banyak yang belum dimanfaatkan dengan baik. Solusi dari permasalahan keterbatasan lahan di daratan tersebut adalah dengan melakukan reklamasi pada daerah pinggir pantai. Reklamasi adalah sebuah kegiatan yang dilakukan dalam rangka meningkatkan manfaat sumber daya lahan yang ditinjau dari sudut lingkungan, sosial dan ekonomi, dengan melalui pengurugan, pengeringan lahan atau drainase. Pada umumnya material untuk pengurugan reklamasi adalah menggunakan tanah kohesif. Pada penulisan ini akan dibahas penggunaan fondasi tiang pancang pada tanah reklamasi. Daya dukung dan volume beton yang digunakan dari setiap bentuk tiang pancang tersebut akan dibandingkan dengan memperhatikan efek scouring yang dapat mengurangi daya dukung pada tiang. Sehingga hasil studi ini akan menunjukan bentuk tiang pancang manakah yang paling cocok digunakan pada tanah reklamasi.
\end{abstract}

Kata kunci: reklamasi, fondasi, tiang pancang, daya dukung, scouring.

\section{PENDAHULUAN}

Indonesia merupakan negara dengan jumlah penduduk terbanyak ke 4 di dunia (https://www.worldometers.info/world-population/) sehingga kota-kota besar di Indonesia memiliki kepadatan penduduk yang tergolong tinggi. Hal tersebut mengakibatkan meningkatknya kebutuhan lahan perkotaan di daratan. Untuk mengatasi meningkatnya kebutuhan lahan tersebut, reklamasi merupakan solusi yang dapat dilakukan. Diatas lahan tersebut dapat dibangun jalan raya, rumah, gedung, jembatan, jogging track, dan lain- lain.

Menurut Peraturan Menteri Perhubungan No PM 52 Tahun 2011, reklamasi adalah pekerjaan timbunan di perairan atau pesisir yang mengubah garis pantai dan atau kontur kedalaman perairan. Tanah pada lahan reklamasi tersebut merupakan tanah landfill. Oleh karena itu harus dilakukan penyelidikan tanah sebelum memulai tahap pembangunan infrastruktur diatas lahan tersebut.

Untuk melaksanakan pembangunan bangunan pada lahan reklamasi, fondasi merupakan salah satu komponen struktur utama penopang beban bangunan tersebut. Fondasi terdiri atas fondasi dangkal dan fondasi dalam, fondasi dangkal biasanya digunakan untuk bangunan yang tidak tinggi sedangkan fondasi dalam digunakan untuk bangunan yang tinggi. 
Fondasi dalam terbagi menjadi fondasi tiang pancang dan fondasi tiang bor. Dalam proses pelaksanaannya di lapangan, fondasi tiang bor dilakukan dengan cara mengebor tanah terlebih dahulu kemudian memasukkan tulangan lalu di cor, sedangkan fondasi tiang pancang dilakukan dengan cara memancang menggunakan alat pancang sampai ditemukan tanah keras.

Kemampuan fondasi tiang menahan beban bangunan diatasnya disebut daya dukung tiang. Daya dukung tiang tersebut secara umum terdiri atas daya dukung selimut dan daya dukung ujung tiang. Kedua daya dukung tersebut menghasilkan daya dukung ultimate, daya dukung ultimate harus lebih besar daripada beban yang dipikul tiang tersebut.

Fondasi tiang pancang terdiri atas fondasi tiang pancang beton, fondasi tiang pancang baja, dan fondasi tiang pancang kayu. Fondasi tiang pancang beton biasanya digunakan untuk bangunan tinggi, fondasi tiang pancang baja biasanya digunakan untuk bangunan yang berukuran kecil, dan tiang pancang kayu biasanya digunakan untuk rumah-rumah panggung atau rumah-rumah adat. Pada saat ini yang paling sering digunakan adalah fondasi tiang pancang beton dan fondasi tiang pancang baja.

Batasan masalah pada penelitian ini adalah sebagai berikut:

1. Parameter tanah yang digunakan merupakan hasillab dan uji lapangan,

2. Beban arus diperhitungkan,

3. Beban dermaga diperhitungkan,

4. Penurunan fondasi diabaikan,

5. Kekuatan bahan tiang diabaikan,

6. Kemiringan fondasi diabaikan,

7. Beban scouring diperhitungkan,

8. Beban debris diperhitungkan.

Rumusan masalah pada penelitian ini adalah sebagai berikut:

1. Daya dukung tiang menggunakan fondasi tiang pancang dengan bentuk yang berbeda-beda,

2. Daya dukung tiang pancang pada tepi tanah reklamasi,

3. Jenis tiang pancang yang paling cocok untuk tepi tanah reklamasi.

Beberapa tujuan dari penelitian ini adalah sebagai berikut:

1. Mengetahui perilaku bentuk tiang pancang terhadap daya dukung tiang pancang,

2. Mengetahui perilaku daya dukung tiang pancang pada tepi tanah reklamasi,

3. Mengetahui jenis dan bentuk tiang pancang yang paling cocok untuk diaplikasikan pada tepi tanah reklamasi.

\section{Jenis Tanah Reklamasi}

Dalam pekerjaan reklamasi dengan urugan, ada beberapa aspek yang dipertimbangkan yaitu antara lain: jenis material, volume kebutuhan material, lokasi sumber material, waktu yang tersedia dan biaya. Sehingga akan berpengaruh pada metode pelaksanaan dan peralatan yang digunakan. Adapun jenis material yang digunakan untuk pelaksanaannya adalah sebagai berikut:

\section{Material Pasir}

Biasanya material pasir yang digunakan untuk urugan adalah yang memiliki kandungan pasir harus tidak melebihi 15\%, jika permukaan dasar tanah merupakan tanah yang lembek, maka persyaratannya harus lebih baik lagi yaitu tidak melebihi $10 \%$.

\section{Material Batu}

Material batu yang digunakan biasanya berupa tumpukan batu atau yang biasa disebut dengan Rubble Mound. Rubble Mound ini berfungsi sebagai konstruksi daerah yang akan direklamasi serta jenis batu yang digunakan untuk rubble mound harus batu yang memiliki daya tahan terhadap erosi dan pelapukan.

\section{Material Tanah}

Material tanah biasanya digunakan sebagai material soil cover atau yang biasa disebut dengan penutup paling atas dari suatu timbunan.

\section{Fondasi Tiang Pancang}

Tiang pancang adalah bagian pada struktur bangunan yang berfungsi untuk mengalihkan beban yang terjadi pada permukaan tanah ke permukaan yang lebih rendah di dalam muka tanah sehingga beban-beban diatas permukaan dipindahkan ke lapisan tanah keras yang letaknya sangat dalam. (Hutami, 2013). Tiang pancang ada 3 jenis yaitu 
tiang pancang kayu, tiang pancang beton dan tiang pancang baja. Saat ini yang sering digunakan adalah tiang pancang beton dan tiang pancang baja. Tiang pancang beton memiliki bentuk lingkaran, segitiga, persegi, segienam, dan segidelapan. Bentuk yang dipilih bergantung pada jenis tanah dan beban yang akan direncanakan. Sedangkan tiang pancang baja biasanya menggunakan $\mathrm{H}$-Beam,

\section{Pemasangan Tiang Pancang}

Pemasangan tiang pancang dilakukan dengan cara dimasukkan ke dalam tanah dengan alat pancang sampai kedalaman yang diperlukan.

\section{Daya Dukung Ujung Tiang}

Rumus daya dukung ujung yang digunakan adalah metode Meyerhof, untuk faktor daya dukung ujung dapat dilihat pada gambar 1.

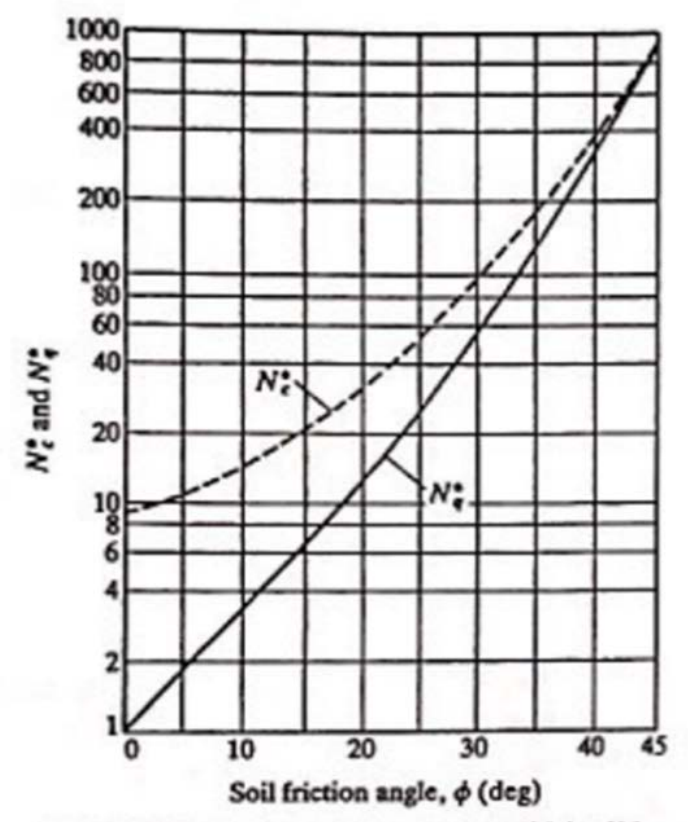

Gambar 1. Faktor daya dukung ujung (Meyerhoff, 1976)

$$
\mathrm{Q}_{\mathrm{p}}=A p C u N c^{\prime}
$$

dengan $\mathrm{Q}_{\mathrm{p}}$ = daya dukung ujung tiang, Ap = luas penampang ujung tiang, $\mathrm{Cu}=$ kohesi tanah, dan Nc' = factor daya dukung ujung.

\section{Daya Dukung Selimut Tiang}

Rumus daya dukung selimut yang digunakan adalah metode Tomlinson $(\alpha)$

$$
\mathrm{Q}_{\mathrm{s}}=f A s
$$

dengan $\mathrm{Q}_{\mathrm{s}}=$ daya dukung selimut tiang, $\mathrm{f}=$ gesekan selimut tiang, dan As = luas selimut tiang.

\section{Daya Dukung Ultimate Tiang}

Rumus daya dukung ultimate tiang adalah

$$
\mathrm{Q}_{\mathrm{u}}=\mathrm{Q}_{\mathrm{p}}+\mathrm{Q}_{\mathrm{s}}-W p
$$

dengan $\mathrm{Q}_{\mathrm{u}}=$ daya dukung ultimate tiang, dan $\mathrm{Wp}=$ berat tiang.

\section{Daya Dukung Lateral Tiang}

Untuk menghitung daya dukung lateral pada tiang, digunakan metode Broms (1964) karena metode ini dapat menghitung tahanan maksimum pada rigid piles maupun long piles yang berada pada lapisan tanah homogen dan murni berupa tanah kohesif atau granuler. Untuk tiang panjang dalam tanah kohesif: 


$$
\begin{gathered}
H_{u}=\frac{2 M_{y}}{1.5 D+\frac{f}{2}} \\
f=\frac{H u}{9 C u D} \\
\mathrm{kp}=\left(\tan \left(45+\frac{\Phi}{2}\right)\right)^{2} \\
\text { Mmax }=\gamma \mathrm{L}^{3} \mathrm{D} \mathrm{kp} \\
\mathrm{My}=\frac{1}{8} A \gamma \mathrm{D}^{2} \mathrm{~L}^{2} \\
\mathrm{Yo}=\frac{\mathrm{Hu} \mathrm{B}}{\mathrm{kh} \mathrm{D}} \\
\mathrm{B}=\left(\frac{\mathrm{kh} \mathrm{D}}{4 \mathrm{Ep} \mathrm{Ip}}\right)^{\frac{1}{4}}
\end{gathered}
$$

dengan $\mathrm{Hu}=$ daya dukug lateral tiang, $\mathrm{My}=$ momen maksimum yang dapat ditahan tiang, $\mathrm{d}=$ diameter tiang, $\mathrm{f}=$ jarak kedalam titik dimana gaya geser sama dengan nol, $\mathrm{Kp}=$ koefisien tanah pasif, dan $\gamma=$ berat volume tanah.

\section{Beban Arus}

Rumus beban arus didapatkan dari FEMA 550

$$
\mathrm{F}_{\mathrm{brkp}}=\frac{1}{2} C D \gamma D \mathrm{H}_{\mathrm{b}}^{2}
$$

dengan $\mathrm{F}_{\mathrm{brkp}}=$ beban arus, $\mathrm{CD}=$ koefisien drag untuk ombak pecah, $\gamma=$ berat jenis air, $\mathrm{D}=$ diameter tiang, dan $\mathrm{H}_{\mathrm{b}}$ $=$ ketinggian ombak pecah.

\section{Beban Debris}

Rumus beban debris didapatkan dari FEMA 550

$$
\mathrm{F}_{\mathrm{i}}=\left(\pi W \mathrm{~V}_{\mathrm{b}} \mathrm{C}_{\mathrm{I}} \mathrm{C}_{\mathrm{O}} \mathrm{C}_{\mathrm{D}} \mathrm{C}_{\mathrm{B}} \mathrm{R}_{\max }\right) /(2 g \Delta t)
$$

\begin{tabular}{|c|c|c|c|c|c|c|}
\hline Tipe Kapal & $\begin{array}{c}\text { Bobot Kapal } \\
\text { (ton) }\end{array}$ & $\begin{array}{c}\text { Displacement } \\
\text { (ton) }\end{array}$ & $\begin{array}{l}\text { Loa } \\
\text { (m) }\end{array}$ & $\begin{array}{c}\text { Lebar (B) } \\
\text { (m) }\end{array}$ & $\begin{array}{c}\text { Tinggi (D) } \\
\text { (m) }\end{array}$ & $\begin{array}{l}\text { Draft } \\
\text { (m) }\end{array}$ \\
\hline Kapal & 1000 & 1333 & 61 & 8,9 & 4,5 & 4,2 \\
\hline Tanker & 5000 & 6667 & 103 & 16 & 6,5 & 6,5 \\
\hline (Oil & 10000 & 13333 & 140 & 17,2 & 7,9 & 7,9 \\
\hline \multirow[t]{2}{*}{ Carrier) } & 15000 & 20000 & 163 & 20 & 11,2 & 8,8 \\
\hline & 20000 & 26667 & 174 & 23,7 & 12,3 & 9,5 \\
\hline
\end{tabular}

dengan $\mathrm{F}_{\mathrm{i}}=$ beban debris, $\mathrm{W}=$ berat debris, $\mathrm{V}_{\mathrm{b}}=$ kecepatan objek, $\mathrm{C}_{\mathrm{I}}=$ importance coefficient, $\mathrm{C}_{\mathrm{O}}=$ orientation coefficient, $\mathrm{C}_{\mathrm{D}}=$ depth coefficient, $\mathrm{C}_{\mathrm{B}}=$ blockage coefficient, $\mathrm{R}_{\max }=$ respon maksimum beban impulsif, $\mathrm{g}=$ gravitasi, dan $\Delta t=$ durasi dari impact.

\section{Beban Dermaga}

Rumus beban dermaga didapatkan dari OCDI (2002), sedangkan untuk data kapal dapat dilihat pada tabel 1.

Tabel 1. Tabel dimensi kapal (Katalog Bridgestone Fender Design Manual) 


$$
E=\frac{1}{2} \mathrm{M}_{\mathrm{s}} V^{2} \mathrm{C}_{\mathrm{m}} \mathrm{C}_{\mathrm{e}} \mathrm{C}_{\mathrm{s}} \mathrm{C}_{\mathrm{c}}
$$

dengan $\mathrm{E}=$ energi tumbukan kapal, $\mathrm{M}_{\mathrm{s}}=$ berat kapal, $\mathrm{V}=$ kecepatan kapal saat merapat, $\mathrm{C}_{\mathrm{m}}=$ koefisien massa, $\mathrm{C}_{\mathrm{e}}$ $=$ koefisien eksentrisitas, $\mathrm{C}_{\mathrm{s}}=$ koefisien kekerasan, dan $\mathrm{C}_{\mathrm{C}}=$ koefisien dari tambatan.

\section{Scouring}

Scouring/gerusan merupakan factor yang dapat mempengaruhi kegagalan lateral dari konstruksi tiang pada bangunan offshore sehingga harus diperhitungkan. Rumus untuk menghitung kedalaman scouring didapat dari FEMA P-550

$$
\mathrm{S}_{\max }=2 a
$$

dengan $\mathrm{S}_{\max }=$ kedalaman scouring maksimum, dan $a=$ diameter fondasi lingkaran atau diagonal maksimum fondasi segiempat.

\section{METODE PENELITIAN}

\section{Studi Literatur}

Pada tahap ini dilakukan studi literatur untuk mengumpulkan teori-teori dan rumus yang digunakan untuk perhitungan analisis.

\section{Pengumpulan Data}

Pada tahapan ini, data tanah yang digunakan merupakan data tanah sebuah proyek reklamasi yang berada di Jawa Timur. Data yang digunakan merupakan data hasil uji SPT (Standard Penetration Test) dan data hasil uji laboratorium.

\section{Pengolahan Data}

Setelah data-data terkumpul dari tahapan sebelumnya, dilakukan pengolahan data tanah dengan menggunakan korelasi-korelasi berdasarkan studi literatur sehingga didapatkan parameter-parameter tanah yang dapat digunakan untuk proses analisis perhitungan daya dukung untuk mendapatkan tiang yang akan digunakan pada proyek di tahapan selanjutnya.

\section{Perhitungan Daya Dukung}

Pada tahapan ini, dilakukan analisis perhitungan daya dukung tiang pancang baik daya dukung aksial maupun daya dukung lateralnya. Perhitungan daya dukung tiang pancang ini dilakukan dengan memperhitungkan semua jenis penampang tiang pancang yang akan diteliti seperti tiang pancang lingkaran, segitiga, persegi, segienam, segidelapan, dan bentuk cincin (spun pile). Pada tahapan ini, yang dijadikan sebagai acuan adalah luas penampang tiang yang sama sehingga volume tiang yang digunakan akan sama semua, sehingga akan diteliti dengan luas penampang yang sama, penampang manakah yang akan menghasilkan daya dukung yang paling besar baik itu aksial maupun lateral.

\section{Tiang Pancang pada Tepi Tanah Reklamasi}

Setelah didapatkan bentuk penampang yang cocok untuk diaplikasikan pada tepi tanah reklamasi, dilakukan analisis perhitungan tiang pancang pada tepi tanah reklamasi dengan memperhatikan faktor-faktor yang mempengaruhi daya dukung tiang pancang pada proyek offshore/pinggir laut seperti pengaruh gerusan (scouring), pengaruh ombak, pengaruh debris (sampah yang terbawa arus), dan pengaruh momen akibat tumbukan kapal. Sehingga kita akan mengetahui perilaku daya dukung tiang pancang pada tepi tanah reklamasi, kemudian dapat ditarik kesimpulan dan saran sebagai hasil dari penelitian ini.

\section{Diagram Alir Penelitian}

Diagram alir penelitian dapat dilihat pada Gambar 2. 


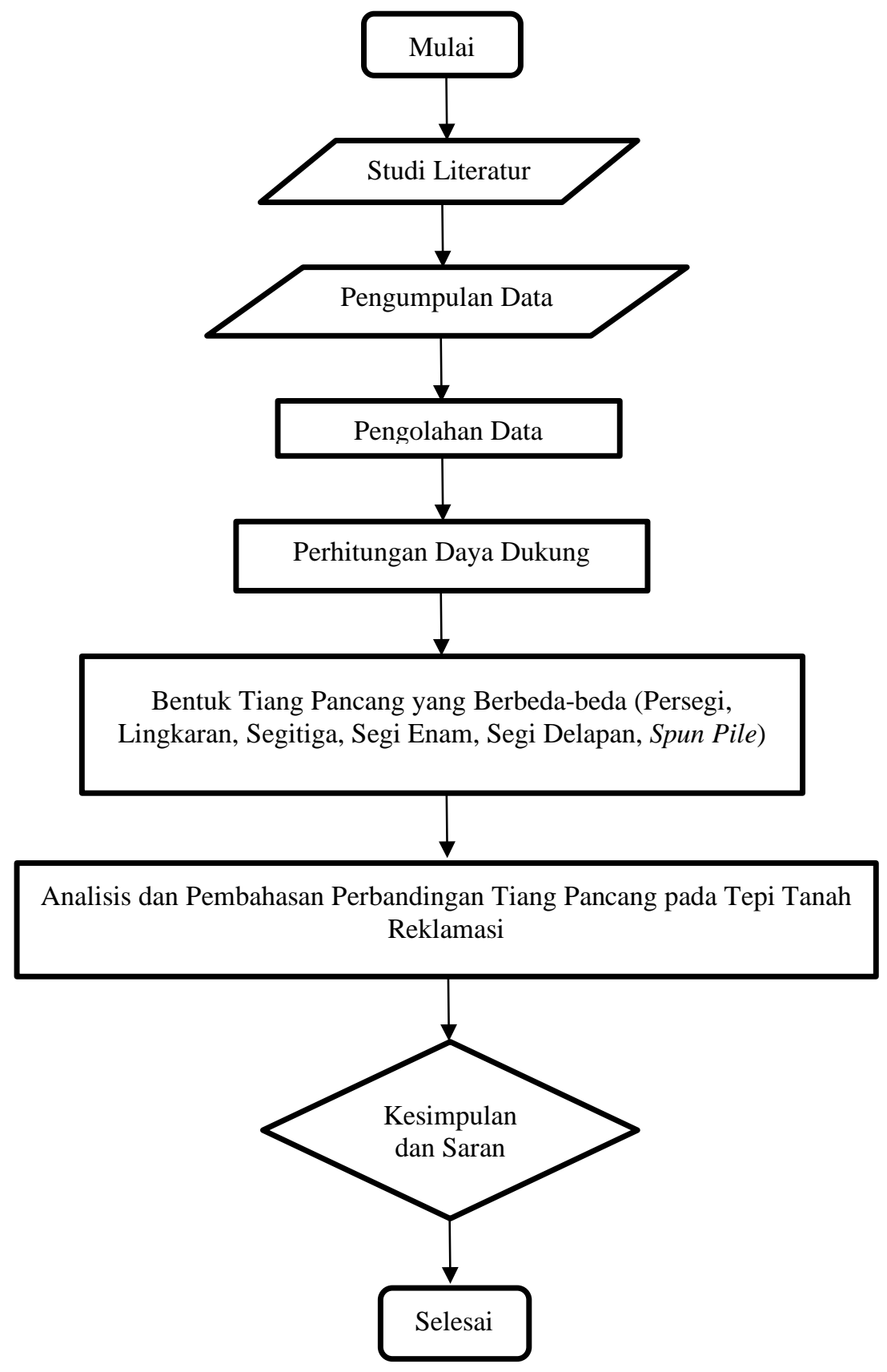

Gambar 2. Diagram Alir Penelitian

Tahapan yang dilakukan pada penelitian ini adalah sebagai berikut:

1. Pengumpulan dan pengolahan data tanah

2. Menghitung daya dukung aksial setiap jenis bentuk tiang pancang

3. Menghitung daya dukung lateral setiap jenis bentuk tiang pancang

4. Memilih bentuk tiang pancang yang paling cocok untuk tanah reklamasi

5. Analisis daya dukung tiang pancang pada proyek reklamasi.

\section{HASIL DAN PEMBAHASAN}

Berikut adalah hasil korelasi parameter tanah berdasarkan data N-SPT. Hasil korelasi parameter tanah dapat dilihat pada Tabel 2. 
Tabel 2. Hasil korelasi parameter tanah

\begin{tabular}{cccccccc}
\hline Kedalaman $(\mathrm{m})$ & Jenis Tanah & $\mathrm{S}_{\mathrm{u}}\left(\mathrm{kN} / \mathrm{m}^{2}\right)$ & $\mathrm{c}\left(\mathrm{kN} / \mathrm{m}^{2}\right)$ & $\gamma\left(\mathrm{kN} / \mathrm{m}^{3}\right)$ & $\phi\left({ }^{\circ}\right)$ & $e$ & $\mathrm{E}_{\mathrm{s}}\left(\mathrm{kN} / \mathrm{m}^{2}\right)$ \\
\hline 0 sd 5 & Clayey Silt & 120 & 240 & 16,3 & 32 & 0,6 & 56000 \\
5 sd 10 & Silty Sand & 25 & 50 & 13,7 & 32 & 0,65 & 15000 \\
10 sd 15 & Clayey Silt & 25 & 50 & 13,8 & 29 & 0,8 & 15000 \\
15 sd 20 & Clayey Silt & 60 & 120 & 14,1 & 30 & 0,6 & 26000 \\
20 sd 25 & Clayey Silt & 90 & 180 & 14,8 & 32 & 0,6 & 82000 \\
25 sd 30 & Silty Sand & 370 & 740 & 17,4 & 31 & 0,57 & 76000 \\
30 sd 35 & Clayey Silt & 110 & 220 & 15 & 32 & 0,57 & 62000 \\
35 sd 40 & Clayey Silt & 125 & 250 & 15,7 & 30 & 0,6 & 74000 \\
40 sd 45 & Clayey Silt & 115 & 230 & 15,3 & 30 & 0,6 & 70000 \\
45 sd 50 & Clayey Silt & 140 & 280 & 16,1 & 30 & 0,6 & 64000 \\
\hline
\end{tabular}

Berdasarkan parameter tanah yang sudah didapatkan, kemudian akan dihitung daya dukung aksial dan lateral semua jenis bentuk tiang pancang. Untuk analisis bentuk tiang pancang, digunakan luas penampang yang sama sebagai acuan, tiang akan diletakkan pada kedalaman $25 \mathrm{~m}$.

\section{Analisis Daya Dukung Aksial dan Lateral Tiang}

Berikut adalah data hasil daya dukung aksial tiang pancang dengan berbagai bentuk. Summary daya dukung aksial tiang pancang dapat dilihat pada Tabel 3, sedangkan summary daya dukung lateral tiang pancang dapat dilihat pada Tabel 4.

Tabel 3. Summary Daya Dukung Aksial Tiang Pancang

\begin{tabular}{cccccc}
\hline Bentuk & $\mathrm{A}\left(\mathrm{m}^{2}\right)$ & $\mathrm{P}(\mathrm{m})$ & $\mathrm{Qp}(\mathrm{kN})$ & Qs $(\mathrm{kN})$ & $\mathrm{Qu}(\mathrm{kN})$ \\
\hline Lingkaran & 0,16 & 1,41810 & 259,2 & 1531,5480 & 500,9160 \\
Segidelapan & 0,16 & 1,45632 & 259,2 & 1572,8256 & 514,6753 \\
Segienam & 0,16 & 1,48897 & 259,2 & 1608,0876 & 526,4293 \\
Persegi & 0,16 & 1,60000 & 259,2 & 1728,0000 & 566,4000 \\
Segitiga & 0,16 & 1,82370 & 259,2 & 1969,5960 & 646,9320 \\
Spun Pile & 0,16 & 1,98555 & 259,2 & 2144,3940 & 705,1980 \\
\hline
\end{tabular}

Berikut adalah data hasil daya dukung lateral tiang pancang dengan berbagai bentuk.

Tabel 4. Summary Daya Dukung Lateral Tiang Pancang

\begin{tabular}{ccccc}
\hline Bentuk & Scouring $(\mathrm{m})$ & My $(\mathrm{kNm})$ & H ijin $(\mathrm{kN})$ & Defleksi $(\mathrm{mm})$ \\
\hline Persegi & 1,13140 & 26,43460 & 25,48370 & 4,43200 \\
Lingkaran & 0,90280 & 34,31270 & 29,65110 & 4,76340 \\
Segitiga & 1,05300 & 46,09960 & 34,74380 & 4,74250 \\
Segienam & 0,99280 & 30,88990 & 27,90050 & 4,64070 \\
Segidelapan & 0,95140 & 32,39330 & 28,67800 & 4,69880 \\
Spun Pile & 1,26400 & 65,26420 & 41,70280 & 3,89380 \\
\hline
\end{tabular}




\section{Pengaplikasian Pada Proyek Reklamasi}

Setelah melakukan analisis daya dukung aksial dan lateral tiang pancang, dipilih tiang pancang jenis spun pile untuk diaplikasikan pada tanah reklamasi dikarenakan dengan luas penampang yang sama, spun pile spun pile dapat menghasilkan daya dukung aksial dan daya dukung lateral paling besar serta defleksi paling minimum. Tiang pancang spun pile yang digunakan adalah dengan diameter luar $1 \mathrm{~m}$ dan diameter dalam $0.7 \mathrm{~m}$ serta dipancang pada kedalaman 25 m. Sketsa potongan spun pile yang digunakan dapat dilihat pada Gambar 3.

Untuk proyek reklamasi yang akan diaplikasikan adalah proyek decking kayu yang berfungsi sebagai tempat bersandarnya kapal dan tempat perkumpulan orang dengan ukuran $10 \mathrm{~m}$ x $5 \mathrm{~m}$ dan bagian sisi 5 m nya akan menjorok ke laut dan tiang akan diletakkan pada 4m sehingga memiliki kantilever $1 \mathrm{~m}$. Site plan dan potongan proyek reklamasi dapat dilihat pada Gambar 4 dan Gambar 5.

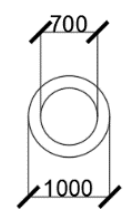

Gambar 3. Sketsa potongan spun pile yang digunakan

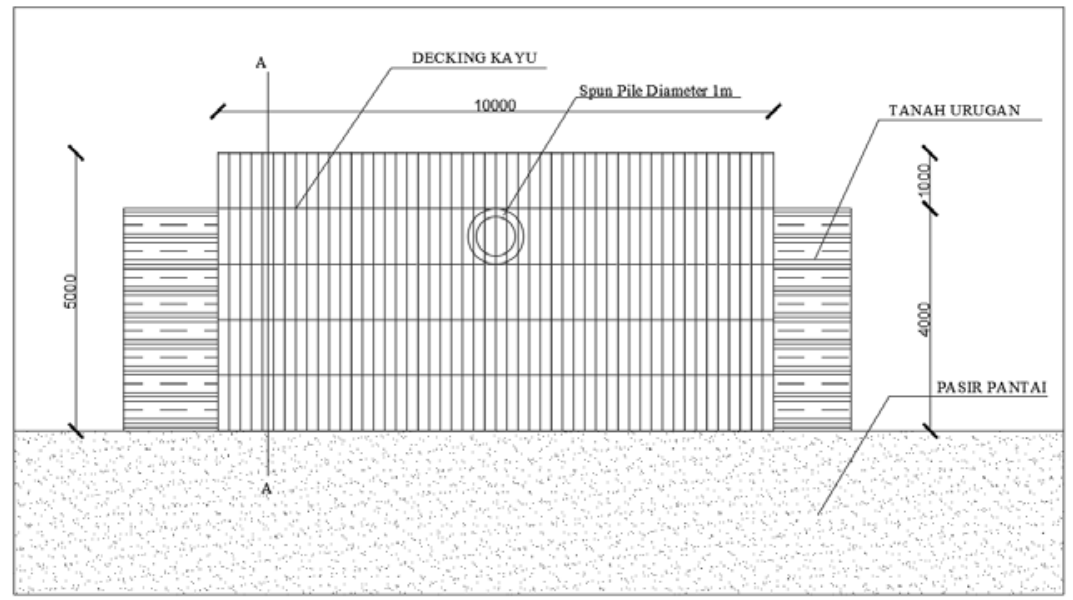

Gambar 4. Site Plan Proyek Reklamasi

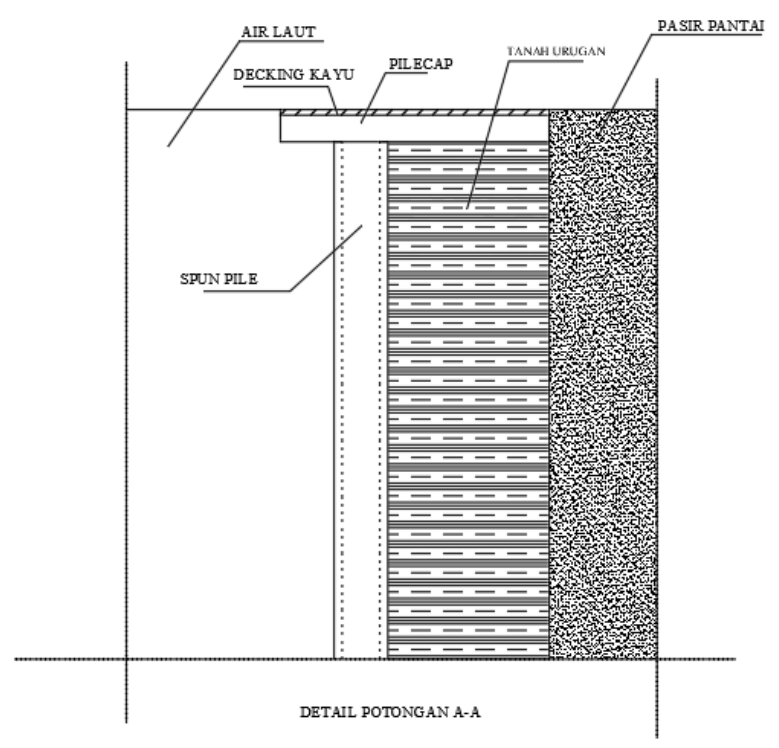

Gambar 5. Detail Potongan A-A 
Setelah dilakukan analisis, didapatkan data tiang sebagai berikut

Diameter luar tiang $=1 \mathrm{~m}$

Diameter dalam tiang $=0,7 \mathrm{~m}$

Daya dukung aksial $=1106,912 \mathrm{kN}$

Daya dukung lateral $=117,6607 \mathrm{kN}$

Momen maksimum tiang $=384,1 \mathrm{kNm}$

Beban-beban yang bekerja adalah sebagai berikut.

Beban Aksial

Beban mati $=361,37 \mathrm{kN}$

Beban hidup $=239,5 \mathrm{kN}$

Kombinasi beban $=816,844 \mathrm{kN}(<$ daya dukung aksial tiang, $\mathrm{OK})$

Beban Lateral

Beban arus $=28,3894 \mathrm{kN}$

Beban debris $=0,9487 \mathrm{kN}$

Total beban Lateral = 28,3894 + 0,9487 = 29,3881 kN (< daya dukung lateral tiang, OK)

\section{Momen}

Momen tumbukan kapal $=102,6297 \mathrm{kNm}$

Momen DL = 36,137 kNm

Momen LL $=23,95 \mathrm{kNm}$

Total Momen $=184,3141 \mathrm{kNm}(<\mathrm{My}$, OK)

\section{KESIMPULAN DAN SARAN}

\section{Kesimpulan}

Berdasarkan hasil perhitungan yang telah dilakukan, dapat disimpulkan beberapa hal, yaitu:

1. Tiang pancang Spun Pile merupakan yang paling cocok untuk tanah reklamasi karena menghasilkan daya dukung aksial yang paling besar, juga menghasilkan daya dukung lateral yang paling besar dan defleksi paling minimum karena dapat menahan gaya lateral dari segala arah dengan baik.

2. Jika ditinjau tiang pancang yang berbentuk padat (tanpa lubang), dapat dilihat pada tabel 3 dan 4, dapat dilihat bahwa bentuk segitiga lah yang memiliki daya dukung aksial dan lateral yang paling besar, tetapi karena bentuk segitiga tidak simetris sehingga kurang cocok digunakan untuk pondasi offshore (banyak beban lateral) karena apabila beban lateral terkena penampang kritisnya akan menghasilkan defleksi yang besar dibandingkan dengan bentuk lainnya.

3. Dari hasil penelitian perhitungan kapasitas daya dukung aksial tiang pancang, dapat dilihat kapasitas daya dukung aksial fondasi tiang pancang dengan luas penampang yang sama dipengaruhi oleh keliling penampang. Semakin besar keliling penampang tiang pancang maka kapasitas dukung akan semakin besar. Sehingga urutan bentuk penampang yang memiliki nilai Qu paling besar adalah penampang lingkaran dengan lubang (spun pile), segitiga, persegi, segienam, segidelapan dan lingkaran.

4. Pada tanah reklamasi, material timbunan yang dominan adalah tanah lanau yang berarti tanah kohesif dan mengakibatkan nilai daya dukung selimut (friction) sangat berpengaruh terhadap daya dukung aksial ultimate.

5. Pada analisis defleksi tiang pancang akibat beban lateral, momen inersia penampang berbanding terbalik terhadap defleksi tiang pancang. Semakin kecil momen inersia penampang, maka defleksi tiang pancang akan semakin besar dan juga sebaliknya.

6. Pada proyek offshore, scouring (gerusan) diperhitungkan karena gerusan tersebut dapat mengakibatkan berkurangnya daya dukung tiang dan mengakibatkan kegagalan pondasi proyek offshore. 


\section{Saran}

Dari hasil penelitian yang telah dilakukan, penulis memberikan beberapa saran untuk melengkapi kekurangankekurangan yang ada, antara lain:

1. Menggunakan software sebagai pembanding hasil perhitungan manual yang telah dilakukan.

2. Melakukan analisis terhadap penurunan pondasi tiang pancang pada tanah reklamasi.

3. Menggunakan data tanah hasil laboratorium agar parameter tanah yang didapatkan lebih tepat daripadah hasil korelasi N-SPT.

\section{DAFTAR PUSTAKA}

Badan Standardisasi Nasional. SNI 4153:2008 Cara Uji Penetrasi Lapangan Dengan SPT. 2008.

Badan Standardisasi Nasional. SNI 8460:2017 Persyaratan Perancangan Geoteknik. 2017.

Bowles, Joseph E. Foundation Analysis and Design (5th Edition). Singapore: The McGraw-Hill Companies, Inc, 1997.

Budhu, Muni. Soil Mechanics and Foundation (3rd Edition). New Jersey: John Wiley \& Sons, 2011.

Das, Braja M. Mekanika Tanah (Prinsip-Prinsip Rekayasa Geoteknis) Jilid 2. Jakarta: Erlangga, 1995.

FEMA P-550. Recommended Residential Construction for Coastal Areas. Building on Strong and Safe Foundations. FEMA , 2019.

https://www.worldometers.info/world-population/. January 2021. January 2021.

Kementerian Perhubungan Republik Indonesia. Peraturan Menteri Perhubungan Nomor PM 52 Tahun 2011 Tentang Pengerukan dan Reklamasi. 2011.

Makarim, Mega Rukmana \& Chaidir A. "Analisis Pemancangan Tiang pada Konstruksi Offshore Pelabuhan di Pulau Jawa terhadap Scouring Effect.” Jurnal Mitra Teknik Sipil. Vol. 2. No. 4 (November 2019): 55-64.

Sri, Hutami. Pondasi. Jakarta: Press, 2013.

The Overseas Coastal Area Development Institute Of Japan (OCDI). Technical Standardization For Port and Harbour Facilities in Japan. Tokyo: Daikousha Printing co, Ltd, 2002.

Wahyudi, Herman. Teknik Reklamasi. Surabaya: Institut Teknologi Sepuluh November, 1997. 